\title{
Compensation for victims of disasters: a task for Europe?
}

Citation for published version (APA):

Faure, M., \& de Smedt, K. (2019). Compensation for victims of disasters: a task for Europe? The Geneva Papers on Risk and Insurance - Issues and Practice, 44(4), 732-759. https://doi.org/10.1057/s41288-01900134-w

Document status and date:

Published: 01/10/2019

DOI:

10.1057/s41288-019-00134-w

Document Version:

Publisher's PDF, also known as Version of record

Document license:

Taverne

Please check the document version of this publication:

- A submitted manuscript is the version of the article upon submission and before peer-review. There can be important differences between the submitted version and the official published version of record.

People interested in the research are advised to contact the author for the final version of the publication, or visit the DOI to the publisher's website.

- The final author version and the galley proof are versions of the publication after peer review.

- The final published version features the final layout of the paper including the volume, issue and page numbers.

Link to publication

\footnotetext{
General rights rights.

- You may freely distribute the URL identifying the publication in the public portal. please follow below link for the End User Agreement:

www.umlib.nl/taverne-license

Take down policy

If you believe that this document breaches copyright please contact us at:

repository@maastrichtuniversity.nl

providing details and we will investigate your claim.
}

Copyright and moral rights for the publications made accessible in the public portal are retained by the authors and/or other copyright owners and it is a condition of accessing publications that users recognise and abide by the legal requirements associated with these

- Users may download and print one copy of any publication from the public portal for the purpose of private study or research.

- You may not further distribute the material or use it for any profit-making activity or commercial gain

If the publication is distributed under the terms of Article $25 \mathrm{fa}$ of the Dutch Copyright Act, indicated by the "Taverne" license above, 


\title{
Compensation for victims of disasters: a task for Europe?
}

\author{
Michael G. Faure ${ }^{1} \cdot$ Kristel De Smedt $^{2}$
}

Received: 25 September 2017 / Accepted: 10 October 2018 / Published online: 5 June 2019

(c) The Geneva Association 2019

\begin{abstract}
Just as in many other regions of the world, the European Union is prone to nearly all types of natural disasters such as earthquakes and floods. Moreover, due to climate change, both the number of incidents and the damage from natural disasters could increase. Natural disasters may cause significant economic losses, and consequently there is a strong demand for compensation for victims in their aftermath. We examine whether, from a theoretical perspective, there is any role to be played at the EU level in the compensation of victims of disasters, particularly in disaster insurance, and even if it were to be just a facilitative role, how this role could take shape in order to stimulate the insurability of natural disasters. We critically examine European initiatives with respect to disaster insurance and ex post compensation and formulate lessons learned on the basis of the theoretical analysis. We explicitly address the question whether the role of the EU should be limited to facilitating insurability or whether it should include providing ex post compensation to states as well.
\end{abstract}

Keywords Climate change $\cdot$ Victim compensation $\cdot$ Disaster insurance $\cdot$ EU

\section{Introduction}

Unfortunately, just as in many other regions of the world, the European Union is prone to nearly all types of natural disasters. Not only do disasters cause human losses but also significant economic losses that affect economic stability and growth. ${ }^{1}$ Moreover, as a result of climate change, both the incidence of and the

1 European Commission, Green Paper on the insurance of natural and man-made disasters, Communication No COM (2013) 213 final, European Commission, Strasbourg, 16 April 2013.

Michael G. Faure

michael.faure@maastrichtuniversity.nl

Kristel De Smedt

k.desmedt@maastrichtuniversity.nl

1 METRO, Maastricht University, P.O. Box 616, 6200 MD Maastricht, The Netherlands

2 Faculty of Law, Maastricht University, P.O. Box 616, 6200 MD Maastricht, The Netherlands 
damage from natural disasters such as flooding, heavy rain and hurricanes could even increase. $^{2}$

The measures taken by the EU Member States with respect to the prevention of these natural disasters and also with respect to the compensation of victims of catastrophes differ widely in scope and form. Increasingly, one notices that the European Commission is becoming active in this domain. For example, in 2013 the Commission issued a Green Paper on natural and man-made disasters ${ }^{1}$ and is actively examining the possibilities of insurance to provide cover for disaster risk. This leads to the question which we want to examine in this paper: whether there is any particular task at the European level with respect to compensation for victims of disasters. We basically distinguish between a role for the EU to facilitate insurability on the one hand, and the provision of ex post compensation to states on the other hand. The advantages and disadvantages of both options are critically discussed.

This article is structured as follows: first, we examine whether there is any particular task at the European level with respect to compensation for victims of disasters on the basis of literature on the economics of federalism. It should be pointed out that in the literature the insurance against disasters is often discussed within the framework of adaptation to climate change. Thus we also ask the question whether Europe should have any particular competence as far as adaptation is concerned. Yet it should be clear that although the question of ex post compensation for victims of disasters is somewhat related to the question of adaptation, it is also different from it. Nevertheless, a lot of the literature, especially that related to federalism, largely focuses on the adaptation issue. We show that the problem is the following: although climate change and (some) disasters may have a transboundary character, the damage is often local. Moreover, it is a domain where solutions adopted in the Member States differ greatly, and so preferences may strongly differ. The methodology we use to analyse the role of central government (in this case the EU) vis à vis subnational entities, including the private sector, will benefit from the literature on the economics of federalism.

As stated above, the European Union is searching for a role with respect to the compensation of victims of natural disasters. Therefore, in the next section we focus on European initiatives to ensure compensation for victims of natural disasters that happen on the territory of the European Union. Here we examine European action with respect to disaster insurance. Disaster insurance allows risk to be transferred financially with a premium paid by the policyholder to the insurer, effectively allowing those in at-risk areas to continue to live and work with low financial impact after a disaster. The question is, of course, whether the European Union would have any task in this respect. Second, the EU has created compensation mechanisms in order to demonstrate solidarity with victims of natural disasters. In particular circumstances the so-called solidarity fund (EUSF) pays the cost of emergency response, mostly aimed at the reconstruction of infrastructure. Moreover, on 26 June 2017 the Council adopted Regulation (EU) 2017/1199 to provide regions hit by earthquakes,

\footnotetext{
2 European Environmental Agency (EEA), https://www.eea.europa.eu/highlights/climate-change-poses -increasingly-severe, last accessed 14 September 2017.
} 
floods or other natural disasters with increased EU support, financed via the European fund for regional development (ERDF). The increased EU financing rate from the ERDF would complement the financial assistance that the EU already provides through its solidarity fund. However, funding solutions have been strongly criticised in the literature as not stimulating insurability. The question arises whether the same criticisms also apply here.

After analysing those EU initiatives that deal with natural disasters and floods in particular, we come back to our main question, notably whether from a theoretical perspective there is any role to be played at the EU level, especially in disaster insurance. We thereby explicitly discuss advantages and disadvantages of two approaches: on the one hand, providing ex post compensation to states, and on the other hand, a more limited role whereby the EU would facilitate insurability. We argue that there is no strong justification for providing ex post compensation to states but that the EU may play a facilitative role, stimulating the insurability of disasters. In that respect, we focus on two particular aspects, the first being data exchange. A crucial element to stimulate the insurability of disasters is the availability of data. Data is largely available from market parties like reinsurers, but EU institutions such as the Joint Research Council are also actively involved in that domain. However, information exchange between (re)insurers has always been viewed with suspicion, given its potential anti-competitive character. For example, in the group exemption on insurance the information exchange between insurers was subject to very strict conditions; therefore, the question is how this information exchange could be stimulated by European action while retaining a sufficiently competitive market. This is related to the second aspect we examine, that is, how the intervention of the government as reinsurer of last resort can be compatible with internal market rules, more particularly related to state aid. The final section concludes.

\section{Is there a task for Europe with respect to disaster insurance? An economics of federalism perspective}

The main aim of this paper is to explore whether there is a role for the EU in developing compensation mechanisms to cover disaster risks and, in particular, disaster insurance. Our central question is whether the EU should (as it currently does to some extent) provide ex post compensation to states or whether it should rather take on a more limited role in facilitating the insurability of disasters. The theoretical perspective to answer the question in this section is the economics of federalism. In this way, we focus our attention more particularly on the literature that analyses whether there should be any role for central institutions like the EU with respect to the adaptation to climate change. This literature can provide useful insights into our central question, as disaster insurance may be one of the instruments in a climate change adaptation policy. ${ }^{3}$

\footnotetext{
3 But climate change adaptation obviously involves more than disaster insurance, and disaster insurance is obviously not only limited to climate change related disasters. However, the theoretical literature with
} 


\section{A traditional environmental federalism perspective}

Environmental federalism scholars traditionally start with a bottom-up approach towards centralisation using the Tiebout Model as the starting point of their analysis.

In 1956 Tiebout developed an ideal model of fiscal competition between independent governments (Tiebout 1956, pp. 415-424; see also Inman and Rubinfeld 2000, pp. 661-691). Tiebout stated that with decentralised, horizontally arranged, competitive governments, individuals could move along local jurisdictions to select the community with a regulatory combination that best satisfies their preferences for public goods. Governments would try to attract residents on the basis of differing tax and benefit structures (Tiebout 1956, pp. 415-424; see also Esty 1996, p. 608). Tiebout's idea is now commonly known as 'voting with the feet' by citizens. Though the Tiebout model was designed for fiscal policies, academic scholars introduced the model to other fields of regulation. The Tiebout model became the starting point for scholars to state that public policies in various fields of regulation should be decentralised.

However, in certain circumstances some oversight at a higher governmental level might be appropriate. Starting from the Tiebout Model, there are four main arguments for centralisation or harmonisation of regulation: the transboundary spillover argument, the race to the bottom argument, the market access argument and noneconomic arguments for centralisation or harmonisation.

First, the Tiebout Model, which favours decentralisation of the provision of public goods, only holds if decisions of one jurisdiction have no external (negative) effects on other jurisdictions. When policies of a certain jurisdiction have a transboundary effect on a neighbouring jurisdiction, there is an argument for centralisation. The reasoning is that jurisdictions will not take into account or 'internalise' the consequences of their actions that might accrue across their borders. Hence, jurisdictions will have no incentive to impose stringent regulation on their own industry and consequently will underregulate the harmful activity (Faure 2003, pp. 38-39; see also Esty and Geradin 2001, p. 34).

A second argument for centralisation is the race to the bottom argument. The term 'race to the bottom' refers to an ongoing relaxation of state regulatory standards caused by interstate competition to attract industry. This relaxation of regulatory standards would result in a reduction of social welfare below the social welfare level that would exist in the absence of this race (Engel 1997, p. 274). If such a risk of destructive competition were to arise, then centralised standard setting might be advanced as a remedy to prevent states from engaging in this welfare-reducing race to the bottom.

Market access presents a third frequently advanced argument for the harmonisation of environmental rules. It is sometimes argued that different levels in the stringency of safety regulations, such as environmental regulation, might cause

Footnote 3 (continued)

respect to climate change adaptation can, as we show in this section, provide useful insights for analysing the role of the EU with respect to disaster insurance. 
trade distortions and hamper access to foreign markets (Esty and Geradin 1997, pp. 266-269). The harmonisation of legal rules would create a level playing field and ease the various competitiveness concerns arising from the intersection of trade liberalisation and safety regulations, such as environmental protection policies (Esty and Geradin 1997, pp. 265-266, see also 1998, pp. 5-46).

In sum, the traditional federalism theory starts from decentralisation, but certain market failures may necessitate oversight at a higher governmental level. Obviously, the question is how climate adaptation policy and disaster insurance fit within this framework.

\section{Insights from democratic experimentalism and adaptive federalism}

Democratic experimentalism is a theory of governance that is intended to encourage continuous improvement in the problem-solving capabilities of local governing units in a federal or decentralised system of government. According to the vision of two founding members, democratic experimentalism places policymaking authority on the local level. A central regulatory authority would exist, but significantly the role of that body would primarily be to support local government, feeding it information regarding the performance of peer local governments and challenging it to do better. The composition of the central governing body would also differ from that of an atypical federal environmental agency, given that it would be populated by representatives from the private and non-profit making sectors (see Beaton 2008, pp. 1700-1701; Dorf and Sabel 1998, pp. 316-318).

The concept of 'adaptive federalism' provides a theoretical framework for a dynamic model of environmental federalism that rejects the static 'matching principle'. ${ }^{4}$ Adaptive federalism rejects the possibility of identifying a single optimal jurisdiction for regulation. Instead, under adaptive federalism and similar ecosystems the interactions of the different regulatory levels tend towards filling gaps and, over time, gradually optimising regulatory outcomes. Adaptive federalism recognises that environmental problems are multi-faceted. As stated by Adelman and Engel (2008, pp. 1796-1799), sources of environmental harm may be the manifestation of numerous failures-market as well as regulatory-that arise along numerous dimensions and on widely different temporal and spatial scales. At the same time, the motivation to address environmental harm will originate from more than one level of government, based upon a variety of social, economic and political variables. This diversity, both in terms of the source of environmental problems and their solution, contributes to policy experimentation on multiple scales and to innovative interactions between regulators on these various scales (Engel 2016, p. 9).

In terms of how it recommends allocating governing authority, democratic experimentalism follows many of the same goals and exhibits many of the same features

\footnotetext{
4 According to the 'Matching Principle', the choice of regulatory jurisdiction is dictated by the perceived geographical scope of the environmental problem in hand. Hence under this principle, localised environmental problems are suitable only for local government regulation, whereas problems of international scope are suitable for agreement by nation states. See also Engel (2016, p. 7).
} 
as dynamic, adaptive federalism. Nevertheless, key differences that divide the two have important implications for environmental issues such as climate change adaptation, and they lack an established governance scheme.

Scholars of democratic experimentalism tend to argue strongly for the location of policymaking authority primarily on the local or subnational level of government rather than welcoming policy responses from all levels of government, including central, national or federal government. Under democratic experimentalism the central authority, in contrast, has a role much like a benevolent parent to provide funding and oversee a peer review. By providing local and central authorities with distinct roles and functions, democratic experimentalism aligns more closely with the 'matching principle' (Engel 2016, pp. 13-14).

In contrast to democratic experimentalism, adaptive federalism rejects the idea of allocating exclusive regulatory authority to a given level of government with minimal overlap with other jurisdictions in favour of overlapping regulation by regulatory authorities at multiple levels of government (Engel 2016, p. 15). On the one hand, dynamic and adaptive federalism values the state and local governments as the primary engines of the development of new policy prescriptions, while on the other hand, it is also considered fundamental that the central government should retain a 'full-service' policymaking role. Only if it does so, can policy ideas truly pass back and forth vertically and, in a re-sizing process, change, adapt and be refined to better suit society's needs. To preclude a role for the central government in policy innovation may result in a bias towards the types of innovations developed. Larger jurisdictions, for example, are more likely to be the source of certain policy innovations. A central government may be more likely to be the source of market-based policies, for example, because central government jurisdictions are more likely to encompass more numerous market participants and hence a more competitive market (Engel 2016, p. 15).

\section{The optimal decision-making level for adaptation to a changing climate}

As explained above, the traditional environmental federalism theory starts from decentralisation. Certain market failures, however, might justify intervention at a higher governmental level. The question that we now have to address is how the arguments of fiscal federalism presented above relate to the central question of our paper, that is, whether there should be any task for the EU as far as disaster insurance is concerned. As already mentioned in the introduction, this question has not as such been explicitly addressed with respect to disaster insurance. However, there is some literature that has addressed whether the criteria of fiscal federalism could justify an EU intervention with respect to adaptation to climate change. As already mentioned, disaster insurance is a mechanism related to climate change adaptation, and in that respect it is interesting to address a few papers, more particularly studies by Engel and Farber, which have examined arguments for the centralisation of climate change adaptation in the U.S. To some extent, those arguments are interesting 
for the EU level as well, although disaster insurance does of course have some specificities that distinguish it from adaptation policy in general.

The case for lodging adaptation with local and regional governing authorities is compelling. Climate change will impact upon human societies and ecosystems in vastly different ways, and much of the variation will be attributable to differences in the natural environment itself. Hence coastal areas will be forced to adapt to rising seas while dry, mountainous areas will need to address the ravages of drought and forest fires, and urban centres the dangers of excessive heat (Engel 2016, p. 18).

At the same time, however, commentators have pointed to the way in which adaptation policy presents many of the same issues that have in the past justified federal regulation: the existence of transboundary spillover effects, political distortions that hinder state response, or equity factors that call for fair treatment across local jurisdictional lines (Farber 2009, p. 259; Glicksman 2009, p. 1159).

Both Farber and Glicksman hold that the same rationales that exist generally in favour of federal regulation apply with equal force with respect to adaptation. Interstate spillovers have long functioned as one of the strongest rationales for federal regulation. But this applies to adaptation as well. They provide the following example: suppose one state refuses to take measures to absorb flood waters when flooding occurs on a water body shared with one or more downstream states. This failure may cause flooding in the downstream states. Similarly, when a state fails to implement water conservation measures with respect to a water body it shares with one or two other states, each of which has implemented water conservation measures, this freeriding behaviour may cause water shortage in other states. Similarly, the other rationales offered for federal regulation could easily exist with respect to adaptation. Take the race to the bottom rationale, whereby in the absence of federal minimum standards, states will engage in a welfare-reducing race to implement lax environmental standards. This could plausibly occur, for instance, where states allow construction in flood plain areas or in storm-prone sensitive coastal areas in an effort to attract economic development (Farber 2009, p. 269; Engel 2016, p. 19). However, one has to be careful with the conclusion that water shortage requires the centralisation of decision-making in all circumstances. Several empirical studies have shown that under specific conditions cooperation among riparian stakeholders may be facilitated. For example, in the U.S. the process of decentralisation has increased the role of subnational states in water resources management. Interactions among these subnational states has created the basis for collaboration in shared river basins. ${ }^{5}$

Much adaptation may come down to what the government-any governmentcan afford to spend on it. Experts predict adaptation costs to be billions of dollars per year (see Wattkiss 2015). The federal government will have greater financial resources available. Imposing the funding obligation upon the federal government may be justified where states are unable to afford adaptation measures or where adaptation measures will affect multiple states (Farber 2009, p. 273; Engel 2016, p. 19).

\footnotetext{
${ }^{5}$ See Moore (2017, pp. 222-239) and other contributions in the special issue of Water International, Vol. 42(2), 2017.
} 
Given the disincentive to fund adaptation measures as well as the justification for local, state and regional involvement, it makes little sense to locate adaptation governance on one level of government. Instead, the dynamic federalism model would seem to fit adaptation, at least in terms of its embrace of regulation of multiple scales of government. In this model the federal, state and regional governing bodies represent alternative sources of policymaking. Dynamic federalism can be expected to promote synergy between government agencies. Given the lack of experience with adaptation policy, it would be foolish to rigidly cut off the source of new solutions from whatever level of government is motivated to act. The dynamic concept of federalism addresses adaptation's need for innovative policy from multiple scales of government (Engel 2016, p. 20).

It might be advantageous to look at other frameworks for more responsive policymaking processes, such as democratic experimentalism, since experimentalism has a lot to offer for adaptation policy (Engel 2016, p. 21).

Commentators uniformly predict that climate change will bring with it dynamic, complex and potentially abrupt ecosystem changes on varying scales. Thus for some, regulations in the service of adaptation should seek to reduce the vulnerability of the ecosystems to abrupt and uncertain change, and to reinforce the resilience of such systems. This process would seem ideally suited for democratic experimentalism-a problem in need of a regulatory system that constantly monitors its effects and updates its requirements. But for others the adaptation will necessitate national (and possibly international) infrastructure and regulations that-together with the necessary minimum standards to even out intra-state issues-will call for federal, state and local regulation similar to traditional federalism (Engel 2016, p. 1).

\section{Summary}

What are some of the lessons of this federalism literature for our central question related to the role of the EU in compensation for victims of disasters? The overview of literature presented in this section argues that the models of democratic experimentalism and collaborative governance call for hybrid solutions of collaboration between central authorities and local authorities with a view to optimal decisionmaking within a multi-level governance framework. The importance of a hybrid solution also applies to the domain of climate change adaptation. Specific adaptation measures can and should be taken at the local level, but a broader framework for structure adaptation can be (and has been) developed at a higher level of governance, more particularly at the EU level. This call of the literature for a hybrid solution would be an argument in favour of a facilitative role for the EU whereby the insurability of disasters in the different Member States would be facilitated, rather than a more active role where, for example, direct ex post compensation to states would be provided. Traditional arguments of the economics of federalism in favour of a strong competence at the central level (such as interstate spillovers or a race to the bottom) are not very convincing as a justification for an EU role in providing ex post compensation to states. 
Currently, the available insurance schemes for disaster risks vary widely in scope and form across Europe. This existing patchwork has arisen for historic and cultural reasons with different perceptions and customs when it comes to dealing with flood risks. Some follow the model that was introduced by France in 1982 that mandatorily adds disaster insurance to other voluntarily purchased insurances such as, for example, housing or fire insurance (for details see Cannarsa et al. 2006, pp. 86-88). The same model also exists in Belgium, Norway and Spain. In addition, the government increasingly intervenes as a reinsurer of last resort to provide cover if reinsurers lack capacity. The Netherlands, on the other hand, has always had a problematic history regarding flood insurance; for a long time flood insurance was prohibited as a result of a so-called binding agreement (basically a cartel between insurers agreeing not to provide flood coverage). After comments from the European anti-trust authorities this binding decision was transformed into a non-binding recommendation (see Faure 2007, pp. 347-348). But the practice did not fundamentally change. It is still extremely difficult to obtain flood insurance in the Netherlands. ${ }^{6}$ The large variety of instruments used to compensate disaster victims within the Member States is often the result of multiple and conflicting views as to what extent the public responses to flood risk should draw on principles of affordability, equity and solidarity. Local customs and traditions, as well as risk perception and attitudes also play an important role in determining the extent of the underwriting of flood insurance products (Surminski et al. 2015, p. 1454). Those existing differences are, together with the absence of strong theoretical justifications, yet another argument against a strong role of the EU in compensating disaster victims.

\section{European initiatives to compensate victims of natural disasters: disaster insurance versus compensation funds}

After having sketched out the theoretical framework for assessing the role of the EU with respect to compensation after disasters in the literature review in the previous section, we now focus on the actual policy at the EU level. We first sketch the general adaptation strategy adopted by the EU as a background. Then we analyse to what extent the EU is currently involved in either of the two approaches central to our paper, those being to facilitate insurability or provide ex post compensation to states. Subsequently, we provide a critical analysis of both options.

\section{EU adaptation strategy}

At the European level various steps have already been taken to adapt to climate change and to minimise the risk on, and the impact of, natural hazards. Adaptation means anticipating the adverse effects of climate change and taking appropriate action to prevent or minimise the potential damage. It has been shown that

\footnotetext{
${ }^{6}$ For a more recent appraisal, see Bruggeman et al. (2011) and Hartlief and Faure (2015, pp. 10301035).
} 
well-planned, early adaptation action saves money and lives later on. ${ }^{7}$ Therefore, after an initial European adaptation framework was set out in a White Paper $^{8}$ in 2009, the European Commission introduced the EU Adaptation Strategy 2013. The strategy sets out a framework and mechanisms for preparing the EU for current and future climate impacts. The strategy has three main objectives: promoting action by Member States; promoting better informed decision-making and promoting adaptation in key vulnerable sectors. With regard to flood risk, climate change must also be properly integrated into the implementation of the Floods Directive. Full implementation of this Directive by the EU Member States will help increase resilience and facilitate adaptation efforts. ${ }^{9}$

\section{Facilitating insurability of disasters}

After increasing losses from disasters, a debate about the role of the EU in shaping disaster insurance has emerged. A Green Paper on the insurance of natural and manmade disasters, addressing the suitability of the insurance conditions in Europe due to the higher occurrence of extreme events accompanied the EU strategy on adaptation to climate change. The Green Paper poses a number of questions concerning the adequacy and availability of appropriate disaster insurance. The objective is to raise awareness and to assess whether or not action at the EU level could be appropriate or warranted to improve the market for disaster insurance in the European Union. ${ }^{10}$

The Green Paper ${ }^{1}$ is a first step towards encouraging insurers to improve the way they help to manage climate change risks. The Commission's aim is to improve the market penetration of natural disaster insurance and to unleash the full potential of insurance pricing and other financial products for risk-awareness, prevention and mitigation, and for long-term resilience in investment and business decisions. ${ }^{11}$

The Green Paper reflects on the concerns about rising risk levels and how they can be accommodated through new and existing flood insurance schemes. Possible options include mandatory insurance, product bundling and public reinsurance or disaster pools. The consultation document frames insurance in two ways: the question of availability and affordability, and the potential to use flood insurance as an instrument for flood prevention and flood damage mitigation. ${ }^{1}$

The crucial question for our paper is whether there is any particular task on the European level in this domain and how EU policy could help address the challenges

\footnotetext{
7 https://ec.europa.eu/clima/policies/adaptation_en.

8 European Commission, factsheet adaptation 2014, p.1. https:/ec.europa.eu/clima/sites/clima/files/docs/ factsheet_adaptation_2014_en.pdf.

9 European Commission, White Paper 'Adapting to climate change: Towards a European framework for action’, Brussels, 1.4.2009 COM (2009) 147 final, 10.

10 European Environmental Agency, 'Mapping the impacts of natural hazards and technological accidents in Europe An overview of the last decade', EEA technical report No 13/2010 Executive summary, 11-12.

11 Communication from the Commission to the European Parliament, the Council, the European Economic and Social Committee and the Committee of the Regions, 'An EU Strategy on adaptation to climate change', COM/2013/0216 final, Brussels, 16.4.2013, 9.
} 
at Member State level. On the basis of our theoretical framework some thoughts can be formulated on a potential task for the EU with respect to disaster insurance. Taking the strict criteria from fiscal federalism (the danger of transboundary externalities and of a race to the bottom), it is not immediately clear why disaster insurance would specifically be a task for the EU. As mentioned earlier, damage resulting from natural disasters is often local, and the solutions worked out so far relating to disaster insurance vary greatly between the EU Member States without so far having caused huge difficulties. The fact that France and Belgium, for example, have mandatory comprehensive disaster cover, but the Netherlands and Germany do not, does not lead to any specific problem such as a transboundary externalisation of harm or a race to the bottom in particular Member States. Of course, it could be considered problematic that in some EU Member States (such as the Netherlands) disaster insurance is not sufficiently available, which may point to the concentrated nature of the particular insurance market. In that sense, rather than thinking about mandatory EU action in this domain, one could examine to what extent EU action might facilitate the availability of disaster insurance.

What is interesting is that the European Parliament uses the same reasoning in its report on the insurance of natural and man-made disasters. ${ }^{12}$ The European Parliament argues that prevention is the most important factor in terms of protecting people and avoiding losses caused by unexpected events. The European Parliament therefore sees a role for the EU in developing a more responsible society which gives enough thought to preventive measures and creating a culture of prevention, enhancing citizens' awareness of both natural and man-made risks. ${ }^{13}$

Therefore, the European Parliament welcomes the Commission's efforts to raise awareness regarding disasters, but underlines that 'the EU should not create overlapping and contradictory liability rules'. The European Parliament further points out that 'in most Member States there is some form of insurance-based system for floods and other natural damage. The system can be supplemented with state funds to compensate for those assets which cannot be privately insured, and state funds may also compensate for insurance claims exceeding the maximum amounts or for otherwise exceptionally heavy damage'. The European Parliament further takes the view 'that a Member State may participate in compensation for damage by providing reinsurance but these systems differ in many respects, and it is not prudent or necessary to unify them'. ${ }^{14}$

It is also interesting that the European Parliament points to the risk of moral hazard if citizens assume that their government will be using public resources from the national budget to cover their losses. The European Parliament is therefore critical of actions and measures which may discourage citizens or communities from taking

\footnotetext{
12 European Parliament, Report on the insurance of natural and man-made disasters (2013/2174(INI)), Committee on Economic and Monetary Affairs, A7-0005/2014, 20.12.2013.

13 European Parliament, Report on the insurance of natural and man-made disasters (2013/2174(INI)), Committee on Economic and Monetary Affairs, A7-0005/2014, 20.12.2013, 4/7.

14 European Parliament, Report on the insurance of natural and man-made disasters (2013/2174(INI)), Committee on Economic and Monetary Affairs, A7-0005/2014, 20.12.2013, 5/7.
} 
measures to protect themselves. Therefore, the European Parliament is of the opinion that citizens should carry their share of responsibility and that compensation should not cover all damage. ${ }^{15}$

The European Parliament also concludes that there is no market distortion in this field to justify intervention at the European level, and therefore the European Parliament does not think that a one-size-fits-all solution would be appropriate, and further points out that tailor-made insurance products depend on many elements such as type of risks, their probable quantity and quality, culture of prevention, state of preparedness and capacity for action and the approach taken by Member States and regional authorities concerning risk monitoring and preparation. ${ }^{15}$

As such, the European Parliament considers that a flexible natural catastrophe insurance market allows insurance companies to adapt products to different conditions, and believes that a non-mandatory framework is the best way to develop products that match natural risks in a given geographical area. So far, no further steps have been taken by the EU Commission.

In sum, at the policy level there does not seem to be support for further centralisation (or harmonisation) of disaster insurance within the EU.

\section{Ex post compensation}

Natural disasters may cause significant economic losses, and consequently there is a strong demand for compensation for victims in the aftermath of a disaster. Also at the European level, funds have been created to fulfil the need to show solidarity with victims.

The European Union Solidarity Fund (EUSF) ${ }^{16}$ was set up in 2002 to respond to major natural disasters and to express European solidarity to disaster-stricken regions within Europe. The EUSF was established following devastating flooding in Central Europe in the summer of that year.

Furthermore, regulation (EU) 2017/1199, adopted on 26 June 2017, provides for the EU to meet up to $95 \%$ of the reconstruction costs of regions affected by earthquakes, floods or other natural disasters. The regulation is the result of a proposal by the EU Commission in the wake of the earthquakes that struck central Italy in 2016.

Funding solutions have been strongly criticised in the literature as not stimulating insurability. However, the question arises whether, given the particular shape of these funds, the same criticisms also apply there.

We first provide a brief summary of the functioning of the European solidarity fund and Regulation (EU) 2017/1199, followed by an economic analysis.

\footnotetext{
15 European Parliament, Report on the insurance of natural and man-made disasters (2013/2174(INI)), Committee on Economic and Monetary Affairs, A7-0005/2014, 20.12.2013, 6/7.

16 Council Regulation (EC) No 2012/2002 of 11 November 2002 establishing the European Union Solidarity Fund, OJ L 311 of 14.11.2002, hereafter EUSF Council Regulation.
} 


\section{The European Union Solidarity Fund}

The European Union Solidarity Fund (EUSF) was set up to respond to major natural disasters and express European solidarity with disaster-stricken regions in Europe. The EUSF was established in 2002 following devastating flooding in Central Europe in the summer of that year. Since then, this fund has been used for 76 disasters covering a range of different catastrophic events including floods, forest fires, earthquakes, storms and drought. Twenty-four different European countries have been supported so far to an amount of over EUR 5 billion. ${ }^{17}$

The main purpose of the EUSF is the provision of assistance to Member States or accession countries whose regions are affected by major natural disasters such as floods, fires, storms, drought and earthquakes with serious effects on the living conditions of the citizens of the affected regions, as well as the economic welfare or the natural environment. ${ }^{18}$

A disaster is considered to be major if the direct damage caused amounts to at least EUR 3 billion $^{19}$ or exceeds $0,6 \%$ of the gross national income (GNI) of the affected state. ${ }^{20}$ The EUSF can also intervene for regional national disasters that affect the majority of the population of a region if it is deemed that the disaster will have serious and lasting effects on the economic stability and living conditions of that region. Furthermore, pursuant to the neighbouring country criterion, those member states or accession states suffering from the impact of the same disaster as another state for which the status of major disaster has already been declared may also receive assistance. ${ }^{21}$

Assistance from the EUSF takes the form of a grant to supplement public spending by the beneficiary state and is intended to finance measures to alleviate noninsurable damage. ${ }^{22}$ Measures eligible for funding are: restoring infrastructure and plants that provide energy, drinking water, waste and water disposal, telecommunications, transport, healthcare and education; the provision of temporary accommodation and the funding of rescue services in order to meet the needs of the population affected; the immediate consolidation of preventive infrastructure and protection of cultural heritage sites; and the cleaning-up of disaster-stricken areas, including natural zones. ${ }^{23}$ Solidarity Fund grants are financed outside the normal EU budget.

\footnotetext{
17 http://ec.europa.eu/regional_policy/en/funding/solidarity-fund/ last accessed 7 September 2017.

18 European Parliament, Directorate General for Internal Policies Policy Department D: Budgetary Affairs. Success Stories: The Use of the EU Solidarity Fund, in-depth Analyses, PE 490.699, 26/11/2014 and EUSF Council Regulation, Article 2.

19 At 2011 prices.

20 EUSF Council Regulation, Article 2 (2).

21 EUSF Council Regulation, Article 2. In Article 2 (2), a region is further defined as a region at NUTS level 2.

22 EUSF Council Regulation, Article 3 (3).

23 EUSF Council Regulation, Article 3.
}

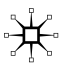


The Regulation did foresee that the Council should review the Regulation on the basis of a proposal from the Commission by 31 December $2006 .^{24}$

Indeed, since its creation it has become clear that changes are needed to live up to the expectations of disaster-stricken countries and regions waiting for EU aid. While the instrument was generally meeting its objectives well, it was considered to be insufficiently responsive, as certain criteria for its activation are too complicated or not sufficiently clear. Moreover, the procedure for granting assistance is lengthy, and it usually takes around one year from the disaster to the payment of the grant. ${ }^{25}$

In 2005 the Commission presented a legislative proposal for a new EU Solidarity Fund Regulation. ${ }^{26}$ Building on the existing fund, this proposal aimed for (1) enlarged scope and wider eligibility of operations to enable the Community to react to disasters other than those of natural origin, e.g., industrial accidents and other man-made disasters, threats to public health (such as pandemics) and major terrorist acts; (2) the possibility to make advance payments to accelerate the rate of response and the visibility of EU support; and (3) simplification through the introduction of clearer criteria for the activation of the Fund. ${ }^{27}$

The proposal was very favourably received by the European Parliament, which adopted the proposal at its first reading on 18 May 2006.

However, in the Council the proposal met with widespread scepticism and opposition among a vast majority of Member States concerning almost all new elements and, in particular, in the light of their potential implications for the budget. To unblock the situation, the Commission proposed, in its communication on the Future of the European Union Solidarity Fund of 6 October 2011, ways to improve the functioning of the fund, but this did not lead to a reboot of the debate.

On 25 July 2013 the Commission presented a new legislative proposal to make the Solidarity Fund faster, clearer and simpler to use. The proposal included the following modifications: speeding-up of payments; the introduction of possible advance payments, a clearer definition of the scope for intervention through the Solidarity Fund, and a simplification of the administrative procedures by combining decisions on the awarding of grants with the implementation agreement. The proposal, negotiated under the ordinary legislative procedure, led to the entry into force of the amending Regulation (EU) No 661/2014 of 15 May 2014. ${ }^{28}$

Furthermore, the reform encourages Member States to put disaster prevention and risk management strategies higher on the agenda. Article 8 (3) obliges beneficiary

\footnotetext{
24 EUSF Council Regulation, Article 14.

25 European Commission, Press Release, Making the EU Solidarity Fund faster and simpler for support after disasters, Brussels, 25 July 2013; European Commission, Memo, Q\&A on the reform of the European Union Solidarity Fund, Brussels, 23 July 2013, IP/13/732.

26 Proposal for a Regulation of the European Parliament and of the Council establishing the European Union Solidarity Fund, COM (2005) 108 final of 6.4.2005.

27 European Commission, Communication from the Commission to the European Parliament, the Council, the European Economic and Social Committee and the Committee of the Regions, The Future of the European Union Solidarity Fund, Brussels, 6.10.2011 COM(2011) 613 final, 7.

28 Regulation (EU) No 661/2014 of the European Parliament and of the Council of 15 May 2014 amending Council Regulation (EC) No 2012/2002 establishing the European Union Solidarity Fund, OJ L189/143, 27.6.2014.
} 
states to present an implementation report in which they describe preventive measures to limit future damage. ${ }^{29}$ As such, the European Commission has taken clear steps to link the Fund to pro-active risk reduction.

\section{Regulation (EU) 2017/1199 of 26 June 2017}

In 2016, earthquakes struck four regions in Central Italy and had a devastating effect on the people living in the area as well as all the capital assets. ${ }^{30}$ Large-scale reconstruction work was required, notably to restore the cultural heritage of the affected areas. In the wake of the earthquakes, Commission President Juncker announced that the EU would stand by Italy and its citizens and help fully reconstruct the areas damaged, including the Basilica of San Benedetto in Norcia. ${ }^{31}$

On 30 November 2016 the Commission produced a specific follow-up to its commitment and published a proposal for a targeted amendment to the 2014-2020 Cohesion Policy regulation. ${ }^{32}$

The Commission argued that Europe needed to be able to provide prompt additional, effective support from the European Regional Development Fund (ERDF) to Member States and regions hit by major or regional natural disasters, complementing the means available under the European Union Solidarity Fund (EUSF). In order to provide such additional assistance to Member States affected by natural disasters, the Commission proposed to introduce the possibility of a separate priority axis for reconstruction operations supported by the ERDF within an operational programme. ${ }^{33}$

Moreover, given the potential magnitude of the impact of natural disasters, it was proposed to provide the possibility to finance reconstruction work by the ERDF with a co-financing rate of up to $100 \%$, hence without the need for national co-financing, on condition that the operations to be financed within this separate priority axis should be those linked to reconstruction in response to major or regional natural disasters as defined in Council Regulation (EC) No 2012/2002 establishing the European Union Solidarity Fund. ${ }^{16,34}$ Normally, the ERDF co-finances projects alongside

\footnotetext{
${ }^{29}$ Regulation (EU) No 661/2014, Article 8.

30 The earthquakes happened on 24 August 2016 and on 27 October 2016.

31 http://europa.eu/rapid/press-release_IP-16-4095_en.htm, last accessed 5-9-2017.

32 Regulation (EC) 1303/2013 of the European Parliament and of the Council of 17 December 2013 laying down common provisions on the European Regional Development Fund, the European Social Fund, the Cohesion Fund, the European Agricultural Fund for Rural Development, and the European Maritime and Fisheries Fund and laying down general provisions on the European Regional Development Fund, the European Social Fund, the Cohesion Fund and the European Maritime and Fisheries Fund and repealing Council Regulation (EC) No 1083/2006, OJ L 347, 20.12.2013..

33 Proposal for a Regulation of the European Parliament and of the Council, amending Regulation (EU) No 1303/2013 as regards specific measures to provide additional assistance to Member States affected by natural disasters, Brussels, 30.11.2016 COM (2016) 778 final, Explanatory Memorandum. See also Regulation (EU) No 1301/2013 of the European Parliament and of the Council of 17 December 2013 on the European Regional Development Fund and on specific provisions concerning the investment for growth and jobs goal and repealing Regulation (EC) No 1080/2006, OJ L 347, 20.12.2013.

34 Proposal for a Regulation of the European Parliament and of the Council, amending Regulation (EU) No 1303/2013 as regards specific measures to provide additional assistance to Member States affected by natural disasters, Brussels, 30.11.2016 COM (2016) 778 final, Explanatory Memorandum.
} 
national funding, with the proportion of ERDF and national funding varying according to the wealth of a particular region. ${ }^{35}$

In its proposal the Commission argued that in order to provide additional assistance to Member States affected by natural disasters an amendment of Regulation (EU) No 1303/2013 was required. The Commission further argued that the proposal was a limited and targeted change not going beyond what is necessary to achieve the objective of providing additional assistance to Member States affected by natural disasters. ${ }^{36}$ Moreover, the amendment remained within the limits of the overall allocation for the period 2014-2020 and was therefore budget neutral. The increased cofinancing rate up to $100 \%$ would lead to a partial front-loading of payments followed by lower payments at a later stage, as the overall envelope is unchanged. ${ }^{36}$

If the proposal were to be adopted, any Member State affected by a natural disaster (as qualified under Council Regulation (EC) No 2012/2002 on EUSF) would be able to activate this form of EU support. Moreover, Member States struck by earthquakes, floods or severe droughts and forest fires could activate this special EU support from day one of a disaster and for disasters that have occurred since the beginning of the current programme period, i.e., 1 January $2014 .{ }^{37}$ It would supplement the EU Solidarity Fund assistance and spare national resources. Moreover, it would provide quick and efficient EU assistance to regions in distress. ${ }^{38}$

On 26 June 2017, Regulation (EU) 2017/1199 of the European Parliament and of the Council of 4 July 2017 amending Regulation (EU) No 1303/2013 regarding specific measures to provide additional assistance to Member States affected by natural disasters was adopted. ${ }^{39}$ In Article 120 of Regulation (EU) No 1303/2013 the following paragraph was added: "a separate priority axis with a co-financing rate of up to $95 \%$ may be established within an operational programme to support operations which fulfil all of the following conditions; the operations are selected by managing authorities in response to major or regional natural disasters as defined in Article 2(2) and (3) of Council Regulation (EC) No 2012/2002; the operations are aimed at reconstruction in response to the natural disaster; and the operations are supported under an ERDF investment priority".

It is remarkable that the EU will in the future bear up to $95 \%$ of the costs instead of the proposed $100 \%$. The U.K. parliament considered the proposal on 19 April 2017 and argued that 'the UK and other Member States have asserted the importance of the principle of national co-financing. In our scrutiny we have expressed sympathy with the Commission's approach but we agree too that co-financing is an

\footnotetext{
35 https://publications.parliament.uk/pa/cm201617/cmselect/cmeuleg/71-xxxvi/7107.htm.

36 Proposal for a Regulation of the European Parliament and of the Council, amending Regulation (EU) No 1303/2013 as regards specific measures to provide additional assistance to Member States affected by natural disasters, Brussels, 30.11.2016 COM(2016) 778 final, p.3.

37 http://europa.eu/rapid/press-release_IP-16-4095_en.htm, Brussels, 30 November 2016.

38 http://www.agripressworld.com/start/artikel/591537/en.

39 Regulation (EU) 2017/1199 of the European Parliament and of the Council of 4 July 2017 amending Regulation (EU) No 1303/2013 as regards specific measures to provide additional assistance to Member States affected by natural disasters, OJ L176/1, 7.7.2017.
} 
important principle for EU structural funding, and there is a risk that this new proposal-however well intended-could start to erode the principle'. ${ }^{40}$

Nevertheless, for some regions the co-financing rate of $95 \%$ almost doubles the EU's financial contribution from the current level of 50\%. Indeed, without changing the volume of national European Regional Development Fund envelopes, it means that a disaster-stricken region with a Cohesion Policy programme that foresees a $50 \%$ co-financing rate, as, for example, most French and German regions, could receive almost double the funding from the EU to finance reconstruction work. Programmes with an $85 \%$ EU co-financing rate, such as the Portuguese region of Madeira, could get an exceptional top-up that would spare public resources in difficult times. $^{41}$

It is interesting that the European Economic and Social Committee (EESC) is of the opinion that it is quite appropriate to use the European Regional Development Fund (ERDF) to complement the EUSF in the event of major disasters, as the two funds share the same ethical principles and certain programmatic criteria for action. Furthermore, the EESC holds that both funds provide further evidence of European solidarity, and the operations that they generally finance work towards the same goals of promoting economic growth and balanced and sustainable development in Europe's regions. The EESC goes even further and argues that the regulation is only applicable to major natural disasters and does not stand in for Member States in the event of disasters where the resulting damage is assessed to be below the amount that the EESC considers to be an excessively high threshold in need of revision. On the other hand, the EESC is also concerned about the rise in the number of disasters, both natural and otherwise, and stresses the need to step up prevention policies. The EESC considers that the European institutions and Member States place insufficient emphasis on prevention. ${ }^{42}$

To sum up, Regulation (EU) 2017/1199 is potentially quite far-reaching, and hence a critical economic analysis would be appropriate.

\section{Analysis}

After having sketched out the actions of the EU so far with respect to the compensation of disasters in the previous section we now analyse the two options (facilitating insurability versus providing ex post compensation) inter alia in the light of the theoretical framework provided in the section "Is there a task for Europe?" but also

\footnotetext{
${ }_{40}$ https://publications.parliament.uk/pa/cm201617/cmselect/cmeuleg/71-xxxvi/7107.htm, last accessed 14 September 2017.

41 http://ec.europa.eu/regional_policy/en/newsroom/news/2017/07/27-07-2017-special-eu-support-incase-of-natural-disasters-enters-into-force-today.

42 Opinion of the European Economic and Social Committee on the 'Proposal for a Regulation of the European Parliament and of the Council amending Regulation (EU) No 1303/2013 as regards specific measures to provide additional assistance to Member States affected by natural disasters, OJ C 173/38, 31.5.2017.
} 
based on other literature. We first address further possibilities to stimulate insurability and then address the ex post compensation to states.

\section{Stimulating insurability through EU action}

The benefits of insurance solutions for disasters have been well documented in the literature. Insurance can boost resilience to natural hazards (see inter alia Faure and Heldt 2017). Insurance can reduce financial burdens and uncertainty and assist economies in dealing with the negative long-term impacts of natural hazards such as flooding (Surminski et al. 2015, p. 1453). Risk pricing may encourage the reduction of exposure and lead to lower damage costs (Kunreuther 1996). The major advantage of an insurance solution (especially when compared to solidarity payments) is that it can promote disaster risk reduction and thus provide a positive incentive for taking preventive measures. The question therefore arises whether specific actions could be undertaken on the EU level to stimulate the insurability of disasters. Two examples will be provided without working them out in full detail.

\section{Information exchange}

One first important aspect in the supply of disaster insurance is obviously that insurers need to have adequate information on the probability that particular disasters may occur. Predictability of the risk is a key element to guarantee insurability (see Faure and Hartlief 2003, pp. 81-87).

As mentioned in the introduction, the EU could to some extent provide information on the probabilities of disasters to insurers, for example via its joint research centre (JRC), and this information could subsequently be used to provide offers to the market. However, another possibility for insurers would be to collaborate on data exchange, which has always been a very touchy subject with competition authorities, because they feared that information exchange, more particularly on data, could endanger competition in insurance markets (see Faure and Van den Bergh 1995). The EU competition authorities accommodated the concerns of insurers by granting two block exemption regulations in 1992 and 2003. Block exemptions protect particular agreements (in this case between insurers) from the application of competition law if the requirements set in the regulations concerning the block exemption are met. These block exemptions were also applicable inter alia to the establishment of a common risk premium by granting two block exemption regulations in 1992 and 2003. Those were applicable to four types of agreements and granted exemptions from competition law under certain conditions. The block exemption regulations applied to: (a) the establishment of common risk premium tariffs, based on collectively ascertained statistics or on the number of claims; (b) the establishment of standard policy conditions; (c) the common coverage of certain types of risks; and (d) the establishment of common rules on the testing and acceptance of security devices. This therefore allowed insurers to collaborate and exchange information on statistics. In 2010, following a consultation and evaluation process, the 
Commission decided to renew the block exemption. However, the renewal applied only to two of the four types of agreements that had been covered by the previous block exemptions: (a) joint compilations, tables and studies; and (b) co-insurance and reinsurance pools. In addition, the EU Commission made it clear more recently that it might completely repeal the block exemptions in the domain of insurance. On 31 March 2017 the insurance block exemption regulation expired and it has not been renewed. ${ }^{43}$ The fact that the EU insurance block exemption regulation has not been renewed implies that from 1 April 2017 insurers themselves must check their compliance with competition law. This raises the question of whether insurers still have the possibility to collaborate, for example as far as data exchange and statistics are concerned, without running the risk of getting into difficulties with the competition authorities. If that were the case, the alternative could be a more prominent role of the JRC in providing basic data enabling the insurability of disasters. Here one notices the difficult trade-off between the need for insurers to be able to rely on statistics and data on the one hand in order to make catastrophic risks insurable, and on the other hand, the justified desire of competition authorities to apply competition law.

\section{The government as the reinsurer of last resort}

The supply of catastrophe insurance has another feature which may endanger the insurability, i.e., the fact that the magnitude of disasters can often be so large as to make it impossible even for the traditional reinsurance market to cover the risk. In order to deal with this problem, an interesting model has been developed that comes down to the government acting as reinsurer of last resort, with the state assuming at least part of the risk for losses from catastrophes. It has been argued in the literature that, provided particular conditions are met, such reinsurance by the government can indeed positively stimulate the insurability of catastrophes (see Bruggeman et al. 2010, pp. 369-390). This intervention by the government is far preferable to solidarity payments as it is a way to stimulate the functioning of the insurance market. In this respect, the question also arises whether the EU could play a facilitative role. A first role to consider would be to have the EU institutions themselves fulfil this role as reinsurer of last resort. However, given the framework of fiscal federalism developed in the previous section, one does wonder why this task should necessarily be taken on by EU institutions rather than by the governments of Member States. There may, however, be another role for the EU. Whenever the government intervenes as reinsurer of last resort this could again be scrutinised by EU (competition) authorities, more particularly since this support could be considered as a prohibited form of state aid. Looking back, one can see that in particular cases the state aid procedure was followed, whereby Member States' authorities argued that it was an intervention which was not distortive, precisely because it supported the functioning

\footnotetext{
${ }^{43}$ European Commission Press Releases Anti-trust: Commission publishes report on functioning of insurance block exemption regulation, 17 March 2016, available at: http://europa.eu/rapid/press-relea se_IP-16-861_en.htm.
} 
of the insurance market. This problem arose inter alia when the Dutch government decided to intervene in the creation of a pool for damage to agricultural property in the Netherlands as a result of heavy rainfall. A second layer was provided by the Dutch government as reinsurer of last resort, which was reported to the European Commission within the framework of the state aid procedure and which was granted authorisation by the European Commission (for details see Bruggeman et al. 2012, pp. 185-241).

This example again shows that in particular circumstances an intervention by government - more particularly as reinsurer of last resort-may be desirable to stimulate the functioning of the insurance market. It may be important precisely because it could allow the functioning of the insurance market and avoid distortive solidarity payments. In that respect, it may be important that the EU authorities (as in the Dutch example) realise that such an intervention can stimulate rather than distort the insurance market and therefore facilitate those particular solutions.

\section{Ex post compensation}

\section{Criticism in law and economics literature}

There has generally been strong criticism formulated in the law and economics literature with respect to ex post compensation by governments, either via a structural compensation fund (such as the EUSF) or via ad hoc solidarity payments. There are generally three problems identified in the literature.

A first major disadvantage of the lump sum payment in government relief is that no incentives are provided to potential victims to take effective preventive measures. Since the payments under government relief do not usually relate to risk, they offer no incentives for taking preventive measures. Of course it will very much depend upon the nature of the disaster whether it is realistic that victims could have taken preventive measures. Preventive measures that need great infrastructural ex ante disaster management will, for the public good reason discussed above, primarily be undertaken by government. Taking structural measures (e.g., to protect a country against tsunamis or against a terrorism risk) will primarily be a government task. However, there are certainly measures that individual potential victims can take, not so much to prevent a (natural) disaster, but rather to limit the impact and damage. As far as flood protection is concerned, for example, an important factor relates to the location decision. Damage could obviously be prevented by not living in floodprone areas. But again the government may be the best situated to know where these flood-prone areas are and could therefore, by means of zoning and refusal of building permits, prevent relocation to those types of areas. However, even when exposed to particular risks, victims can to some extent take preventive measures (e.g., in the case of flooding by not keeping the most valuable objects in the cellar or on the ground floor). These measures may be relatively limited compared to the impact of infrastructural work that a government could undertake, but they remain important. The problem is that ex post recovery by government may not provide incentives to take those appropriate preventive measures (for further examples see Bruggeman 
et al. 2011). In that respect, the literature argues that competitive insurance markets are better able to deal with moral hazard and adverse selection via risk differentiation (Priest 1996).

A second problem is that victims may be counting on government compensation, which may therefore create an incentive not to purchase insurance (Levmore and Logue 2003, p. 281; Kaplow 1991). The problem of government-provided compensation is indeed that it may dilute incentives to purchase insurance, since victims could simply freeride on the state (Gron and Sykes 2002, 2003; Endres et al. 2003, p. 290). In the words of Gollier: 'Solidarity kills market insurance' (Gollier 2005, p. 25). Coate has identified a lack of insurance resulting from the generosity of the government (Coate 1995). The problem has been referred to as the 'charity hazard' (more particularly by Raschky and Weck-Hannemann 2007). Also, an experimental study on crop insurance in the Netherlands showed that the willingness of producers to purchase private insurance (supported by government) had a significant negative influence on the producer's belief in the availability of disaster relief in the future. ${ }^{44}$ The study concludes that if governments continue to provide free ad hoc disaster relief, an important incentive to participate in crop insurance programmes would be severely undermined. ${ }^{45}$ Recently, a similar conclusion was also reached based on empirical research comparing compensation mechanisms available in different countries after the August flood of 2005 in Austria, Switzerland and the German state of Bavaria (see Raschky et al. 2009). The study argues that there was a substantial charity hazard leading to a lower purchase of insurance in Austria, where there was a disaster fund that pays (low) amounts of compensation. Participation in flood insurance was higher in Bavaria, although it was highest in the Swiss canton of Grisons, which had a public monopoly insurance with mandatory participation (see Raschky et al. 2009).

A related problem is that there may be negative distributional effects, since some victims (who probably purchased houses at low prices in flood-prone areas) may freeride on other individuals (the general tax payers) who finance the ex post recovery.

\section{Application of the case of the EU}

There are, however, some reasons to rethink this criticism. A first important reason is that the payments from the EUSF and the ERDF, as was made clear in the description above, are not paid directly to victims of disasters but rather to governments. The question therefore arises whether the same type of moral hazard that may occur with victims of disasters could also play a role with the EUSF. A second issue is that the payments from the EUSF are not so much geared towards ex post compensation of victims (usually qualified as recovery) but more towards immediate relief. The same seems to be the case for the newly established European Regional Development Fund (ERDF); in fact, it only complements (although very generously)

\footnotetext{
${ }^{44}$ With respect to a crop insurance programme in the Netherlands see Van Asseldonk et al. (2002).

45 Ibid.
} 
the means available under the EUSF and provides additional assistance directly to Member States but not to victims.

In the literature it has been argued that much of the criticism with respect to ex post intervention by the government in cases of (natural) disasters mostly applies to recovery. Recovery is an ex post intervention needed to return the social welfare trajectory to where it would have been had the disaster never occurred (Leonard and Howitt 2010). Recovery consists of two kinds of efforts: reconstruction activities and victim compensation. Reconstruction activities are typically aimed at restoring public services and the country's infrastructure such as roads, harbours and railways. Compensation is usually intended to compensate victims for property losses. Recovery is distinguished from relief. Relief efforts consist of executing an effective, damage-limiting response immediately after an event. For example, in the immediate aftermath of a hurricane people may need basic temporary shelter; then they may need transitional housing while they find a new place to settle or while their former homes are cleaned up, repaired and/or rebuilt; and they may need help with these processes (Sugarman 2007, p. 32). The literature has indicated that the moral hazard which arises in case of ex post actions by the government may play a role in the case of recovery but less of a role in the case of relief. The general point is that intervention that is too generous ex post will affect incentives for prevention ex ante- to the extent that the victims' expectation of political intervention recovery reduces the incentive to take precautions. The situation is different, however, with respect to the effects of relief on prevention. Relief interventions are quick and tailored to the situation. Moral hazard is less of a problem for relief activities, as relief does not provide full compensation but merely mitigates further damage (see Dari-Mattiacci and Faure 2015, p. 199).

At first sight, the EUSF seems to focus strongly on relief efforts. The Council Regulation 2012/2002 of 11 November 2002 that established the European Union Solidarity Fund discussed above makes it clear inter alia in its Article 3 that the essential aim of the EUSF is "to help the beneficiary state to carry out the following essential emergency operations, depending on the type of disaster". The examples that follow clearly focus on what would usually be considered to be relief efforts, such as (a) the immediate restoration to working order of infrastructure, (b) the provision of temporary accommodation and funding for rescue services to meet the immediate needs of the population concerned, (c) the immediate securing of preventive infrastructures, and (d) the immediate cleaning up of disaster-stricken areas.

Now that the EUSF focuses more strongly on relief rather than on recovery it would seem at first that the payments by the EUSF do not necessarily negatively affect incentives as is the case with recovery. However, this (positive) conclusion may have been reached too soon. The conclusion in the literature that relief efforts do not generally affect ex ante preventive efforts may be correct as far as the potential victims exposed to natural disasters are concerned; the situation may, however, be different with respect to the governments that are the beneficiaries of the EUSF. In this respect, we should point to some important research by Depoorter, who indicated that incentives for investment in disaster prevention by politicians are often distorted and, as a result, politicians will often oversupply ex post recovery and underinvest in prevention (Depoorter 2006). The general problem is that the 
likelihood of having to pay ex post relief or recovery in the future does not apparently provide any positive incentives to politicians to invest in disaster prevention mechanisms. Politicians receive little reward from ex ante disaster management policies, and therefore they may be undersupplied. The political reward for ex post compensation may, on the contrary, be very strong and, as a result, ex post relief is likely to be oversupplied (Depoorter 2006). In this respect, the situation with the newly installed ERDF is far more problematic. The ERDF does indeed go much further than merely providing immediate relief after the disaster and also aims at ex post reconstruction. The criticism formulated in the literature with respect to ex post recovery therefore fully applies to the newly created ERDF.

Empirical evidence shows that disaster expenditure is often politically motivated: in the U.S. those states that are politically important to the president have a higher rate of disaster declaration by the president, and disaster expenditure is higher in states having congressional representation on oversight committees of the U.S. Federal Emergency Management Agency (FEMA) (Gerrett and Sobel 2003). Politicians prefer concentrated benefits (for victims living in hazard-prone areas) and diffuse costs (to tax payers). That explains why there is often overinvestment in recovery after disasters, especially when there is extraordinary media coverage (Moss 2010).

This literature obviously has important consequences, also for the analysis of both the EUSF and the ERDF. In fact, just as there may be distorted incentives for domestic governments to grant ex post recovery to victims of natural disasters as well as for underinvestment by victims counting on ex post recovery, the same effect may equally occur in the relationship between the EUSF, ERDF and the domestic governments that may benefit from the payments. The general problem remains that governments, obviously also at the EU level, systematically underinvest in prevention against disasters due to the lack of political reward. The major reason is due to time inconsistency: investments in prevention against future disasters may lead to costs to current tax payers, whereas benefits could only be provided to potential victims in a distant future. Politicians suffering from the NIMTOF syndrome ${ }^{46}$ will therefore not benefit from investments in prevention that may only deliver benefits to future voters. The fact that the EUSF and ERDF now make it possible for EU governments to call on this solidarity fund actually rewards their underinvestment in prevention and therefore contributes precisely to the distorting effects of solidarity payment, just as in the case of charity hazards with victims of natural disasters. Moreover, just as domestic governments have a tendency to oversupply ex post recovery because of the political rewards it provides (see already Hirshleifer 1953), one can argue that the EUSF provides an excellent legitimising function for the European authorities to show their care and concern at the time of a disaster. In the end, both the EUSF and the recently created funding mechanism via the ERDF will be financed by the other EU Member States.

Looking at the history of the EUSF, it becomes clear that in practice it has been nothing less than a large redistribution mechanism. Of the grand total of EUSF aid approved since 2002 (EUR 5,242.29 million), approximately EUR 4000 million

46 NIMTOF: not in my term of office. 
was paid to only five EU Member States. Indeed, it is doubtful whether these types of direct solidarity payments to EU Member State governments are the most appropriate way of providing incentives for adequate investments in disaster risk reduction, especially as the data shows that some of the governments that most benefited from the EUSF are typically the larger EU Member States, such as Germany (EUR 1002.9 million), Italy (EUR 2515.7 million), Austria (EUR 170.74 million), France (EUR 252.6 million) and the United Kingdom (EUR 222.6 million). However, this is not surprising, given that the larger Member States also pay larger contributions. ${ }^{47}$

Payments by the EUSF could be seen to provide distorted incentives-just as in the case of victims of natural disasters on the domestic level-whereas insurance has been argued to be a more appropriate incentive mechanism (see especially Kunreuther 1968). All the problematic aspects of this EUSF are in fact re-enforced in the ERDF, since that provides even more generous compensation (up to 95\%) and also pays for reconstruction.

If particular EU Member States really encountered immediate financing problems in times of natural disaster, an obvious alternative would be to consider sovereign insurance. The World Bank has examined the possibility of sovereign natural disaster insurance-especially for developing countries-to solve the short-term liquidity need (for Ghesquiere and Mahul 2007). Whereas insurance (via risk differentiation) always provides incentives for disaster risk reduction (see Priest 1996), unconditional solidarity payments do not.

\section{Summary}

To sum up, European solidarity funds could learn a lot from the literature on solidarity payments by domestic governments to victims of disasters. An important part of that literature, criticising ex post recovery and pointing to the distorted incentives of politicians to underinvest in prevention and overinvest in recovery, may to some extent play an important role with respect to these European solidarity funds as well.

\section{Conclusion}

The main question that we wanted to examine in this article was whether there is any particular task for the European Union with respect to compensation for victims of disasters, in particular in disaster insurance. In addition, we distinguished between two possible approaches: one in which the role of the EU would be limited to facilitating the insurability of natural disasters and another in which the EU would provide ex post compensation to states.

We used the economic literature with respect to federalism to analyse the optimal division of labour between the Member States and the EU level. The

\footnotetext{
47 See the data on the factsheet of the EU Solidarity Fund on their website, providing an overview of EU Solidarity Fund interventions since 2002. https://ec.europa.eu/regional_policy/sources/thefunds/doc/inter ventions_since_2002.pdf.
} 
literature has paid some attention to the related problem of adaptation to climate change where disaster insurance, more particularly for flooding, also plays an important role. The literature, or more specifically the models of democratic experimentalism and collaborative governance, call for hybrid solutions of collaboration between central authorities and local authorities with a view to optimal decision-making within a multi-level governance framework. This can be recognised in the domain of climate change adaptation and disaster insurance, as many adaptation measures should of course be taken at the local level, but a broader framework could be (and has been) developed at the EU level.

Applying these theoretical insights to the question of which particular form the role of the EU should take with respect to compensating disasters, a case can be made for limiting the role of the EU to facilitating insurability. There are, however, fewer reasons to expand this role to provide ex post compensation to states. Current EU policy only partially corresponds to these recommendations. There seems to be a willingness to stimulate the insurability of natural hazards and a general reluctance to move EU intervention further into that specific area, for example by harmonising insurance. That tendency is in line with the theoretical insights. However, even though the theoretical framework does not provide clear justifications for an EU role in providing ex post compensation to states, this is actually taking place via the EUSF and the ERDF, as we discussed in the section "European initiatives ..." These compensation funds were created by the EU to show solidarity with the victims of disasters.

We argued that we could learn a lot from the literature related to solidarity payments by domestic governments to victims of disasters. An important part of that literature, criticising ex post recovery and pointing to the distorted incentives of politicians to underinvest in prevention and overinvest in recovery may to some extent play an important role in these European compensation funds as well. These payments may potentially have serious adverse effects, more particularly related to the fact that Member States themselves might not invest sufficiently in preventive measures.

So, coming back to our question of what the task of the European Union should be with respect to compensation for victims of disaster, we argue that the European Union could rather play a facilitative role by providing information or by acting as an insurer of last resort in order to stimulate insurability. There are, however, fewer arguments in favour of the EU providing ex post compensation to states. Not only is there no strong theoretical justification, but the literature equally points to the potentially adverse effects of those ex post compensation mechanisms and, more particularly, a negative effect on the incentives to invest in disaster risk reduction.

\section{References}

Adelman, D., and K. Engel. 2008. Adaptive federalism: The case against reallocating environmental regulatory authority. Minnesota Law Review 92 (6): 1796-1850. 
Beaton, B.J. 2008. Walking the federalist tightrope: A national policy of state experimentation for health information technology. Columbia Law Review 108 (7): 1670-1717.

Bruggeman, V., M.G. Faure, and K. Fiore. 2010. The government as reinsurer of catastrophe risks? The Geneva Papers on Risk and Insurance-Issues and Practice 35 (3): 369-390.

Bruggeman, V., M.G. Faure, and M. Haritz. 2011. Remodelling reparation: Changes in the compensation of victims of natural catastrophes in Belgium and the Netherlands. Disasters 35 (4): $766-788$.

Bruggeman, V., M.G. Faure, and T. Heldt. 2012. Insurance against catastrophe: Government stimulation of insurance markets for catastrophic events. Duke Environmental Law \& Policy Forum 23 (1): $185-241$.

Cannarsa, M., F. Lafay, and O. Moréteau. 2006. France. In Financial compensation for victims of catastrophes. A comparative legal approach, ed. M. Faure and T. Hartlief, 81-118. Vienna: Springer.

Coate, S. 1995. Altruism, the Samaritans dilemma and government transfer policy. American Economic Review 85 (1): 46-57.

Dari-Mattiacci, G., and M.G. Faure. 2015. The economics of disaster relief. Law \& Policy 37 (3): 180-208.

Depoorter, B. 2006. Horizontal political externalities: The supply and demand of disaster management. Duke Law Journal 56: 101-125.

Dorf, M.C., and C.F. Sabel. 1998. A constitution of democratic experimentalism. Columbia Law Review 98 (2): 267-473.

Endres, A., C. Ohl, and B. Rundshagen. 2003. Land unter! Ein institutionenökonomischer Zwischenruf. List Forum für Wirtschafts- und Finanzpolitik 29: 284-294.

Engel, K.H. 1997. State environmental standard-setting: Is there a "race" and is it "to the bottom"? Hastings Law Journal 48: 271-398.

Engel, K.H. 2016. Policy innovation under dynamic, adaptive federalism and democratic experimentalism compared: Lessons for federalism and climate change adaptation policy. Arizona Legal Studies, discussion paper no. 16-01. Tempe: Arizona State University.

Esty, D.C. 1996. Revitalizing environmental federalism. Michigan Law Review 95 (3): 570-653.

Esty, D.C., and D. Geradin. 1997. Market access, competitiveness, and harmonization: Environmental protection in regional trade agreements. Harvard Environmental Law Review 21: 265-336.

Esty, D.C., and D. Geradin. 1998. Environmental protection and international competitiveness, a conceptual framework. Journal of World Trade 32: 5-46.

Esty, D.C., and D. Geradin. 2001. Regulatory co-opetition. In Regulatory competition and economic integration. Comparative perspectives, ed. D.C. Esty and D. Geradin, 30-46. New York: Oxford University Press.

Farber, D. 2009. Climate adaptation and federalism: Mapping the issues. San Diego Journal of Climate and Energy Law 1: 259-286.

Faure, M.G. 2003. How law and economics may contribute to the harmonisation of tort law in Europe. In Grundstrukturen des Europäischen Deliktsrechts, ed. R. Zimmermann, 31-82. Nomos: Baden-Baden.

Faure, M. 2007. Financial compensation for victims of catastrophes: A law and economics perspective. Law \& Policy 29 (3): 339-367.

Faure, M., and T. Hartlief. 2003. Insurance and expanding systemic risks. Paris: OECD.

Faure, M.G., and T. Heldt. 2017. Resilient compensation mechanisms: The role of government intervention in the insurance of catastrophic risks. In Law and the management of disasters. The challenge of resilience, ed. A. Herwig and M. Simoncini, 224-244. Oxon: Routledge.

Faure, M., and R. Van den Bergh. 1995. Restrictions of competition on insurance markets and the applicability of EC antitrust law. Kyklos 48 (1): 65-85.

Gerrett, T.A., and R. Sobel. 2003. The political economy of FEMA disaster payments. Economic Inquiry 41 (3): 496-509.

Ghesquiere, F. and O. Mahul. 2007. Sovereign natural disaster insurance for developing countries: A paradigm shift in catastrophe risk financing. Policy Research working paper, WPS4345. Washington, DC: The World Bank.

Glicksman, R.L. 2009. Climate change adaptation: A collective action perspective on federalism considerations. Environmental Law 40 (4): 1159-1193.

Gollier, C. 2005. Some aspects of the economics of catastrophe risk insurance. In Catastrophic risks and insurance, vol. 8, ed. OECD, 13-30. Paris: OECD Publishing. 
Gron, A., and A.O. Sykes. 2002. A role for government? Regulation 25 (44): 44-51.

Gron, A., and A.O. Sykes. 2003. Terrorism and insurance markets: A role for the government as insurer? Indiana Law Review 36: 447-463.

Hartlief, T., and M. Faure. 2015. Vergoeding van schade bij rampen in België en Nederland. Tijdschrift voor Privaatrecht 52 (3-4): 991-1053.

Hirshleifer, J. 1953. War damage insurance. The Review of Economics and Statistics 35 (2): 144-153.

Inman, R.P., and D.L. Rubinfeld. 2000. Federalism. In Encyclopedia of law and economics, ed. B. Bouckaert and G. De Geest, 661-691. Cheltenham: Edward Elgar Publishing.

Kaplow, L. 1991. Incentives and government relief for risk. Journal of Risk and Uncertainty 4 (2): $167-175$.

Kunreuther, H. 1968. The case for comprehensive disaster insurance. The Journal of Law and Economics 11 (1): 133-163.

Kunreuther, H. 1996. Mitigating disaster losses through insurance. Journal of Risk and Uncertainty 12 (2-3): 171-187.

Leonard, H.B., and A.M. Howitt. 2010. Acting in time against disasters: A comprehensive risk-management framework. In Learning from catastrophes: Strategies for reaction and response, ed. $\mathrm{H}$. Kunreuther and M. Useen, 18-41. Saddle River, NJ: Pearson Prentice Hall.

Levmore, S., and K.D. Logue. 2003. Insuring against terrorism-and crime. Michigan Law Review 102 (2): $268-327$.

Moore, S.M. 2017. The dilemma of autonomy: Decentralization and water politics at the subnational level. Water International 42 (2): 222-239.

Moss, D.A. 2010. The peculiar politics of American disaster policy: How television has changed federal relief. In The irrational economist: Making decisions in a dangerous world, ed. E. MichelKerjan and P. Slovic, 151-160. New York: PublicAffairs Books.

Priest, G.L. 1996. The government, the market and the problem of catastrophic loss. Journal of Risk and Uncertainty 12 (2-3): 219-237.

Raschky, P., and H. Weck-Hannemann. 2007. Charity hazard-A real hazard to natural disaster insurance. Environmental Hazard 7 (4): 321-329.

Raschky, P., R. Schwarze, M. Schwindt, and H. Weck-Hannemann. 2009. Alternative financing and insurance solutions for natural hazards. A comparison of different risk transfer systems in three countries-Germany, Austria and Switzerland-affected by the August 2005 floods. Innsbruck: AlpS GmbH Centre for Natural Hazard and Risk Management.

Sugarman, S.D. 2007. Roles of government in compensating disaster victims. Issues in Legal Scholarship $6(3)$ : 1-33.

Surminski, S., J.C.J.H. Aerts, W.J. Botzen, P. Hudson, J. Mysiak, and C. Pérez-Blanco. 2015. Reflections on the current debate on how to link flood insurance and disaster risk reduction in the European Union. Natural Hazards 79 (3): 1451-1479.

Tiebout, C. 1956. A pure theory of local government expenditures. Journal of Political Economy 64 (5): 416-424.

Van Asseldonk, M., M. Meuwissen, and B. Huirne. 2002. Belief in disaster relief and the demand for a public-private insurance program. Applied Economic Perspectives and Policy 24 (1): 196-207.

Wattkiss, P. 2015. ECONADAPT. The costs and benefits of adaptation. Results from the ECONADAPT project. ECONADAPT.

Publisher's Note Springer Nature remains neutral with regard to jurisdictional claims in published maps and institutional affiliations.

\section{About the authors}

Dr. Michael G. Faure LL.M. is academic director of the Maastricht European Institute for Transnational Legal Research (METRO) and professor of Comparative and International Environmental Law at the law faculty of Maastricht University. In addition, he is part-time professor of comparative private law and 
economics at the Rotterdam Institute of Law and Economics (RILE) of the Erasmus University and academic director of the European Doctorate in Law and Economics (EDLE) programme. He is the author of numerous publications including articles in internationally refereed journals and books with renowned international publishers.

Kristel De Smedt is Assistant Professor at Maastricht University, Faculty of Law. She holds both an economics degree and a European law degree. She has published extensively on liability for environmental damage. Her recent research includes articles in international academic journals such as RECIEL (Review of European Community \& International Environmental Law), ZEuP (Zeitschrift für Europäisches Privatrecht) and Environmental Liability and in books on the transposition and the practical effectiveness of the Environmental Liability Directive in the Member States. 